\title{
Plant morphology and herbage accumulation of signal grass with or without fertilization, under different light regimes
}

\section{Clenardo Macedo Lopes ${ }^{1}$ Domingos Sávio Campos Paciullo ${ }^{2 *}$ Saulo Alberto do Carmo Araújo ${ }^{1}$ Mirton José Frota Morenz ${ }^{2}$ Carlos Augusto de Miranda Gomide ${ }^{2}$ Rogério Martins Maurício $^{3}$ Thiago Gomes dos Santos Braz}

${ }^{1}$ Universidade Federal dos Vales do Jequitinhonha e Mucuri (UFVJM), Diamantina, MG, Brasil.

${ }^{2}$ Embrapa Gado de Leite, Juiz de Fora, MG, Brasil. E-mail: domingos.paciullo@embrapa.br. "Corresponding author.

${ }^{3}$ Universidade Federal de São João Del Rei (UFSJ), São João Del Rei, MG, Brasil.

${ }^{4}$ Universidade Federal de Minas Gerais (UFMG), Montes Claros, MG, Brasil.

\begin{abstract}
The silvopastoral system has been suggested as an alternative to recover degraded pastures in tropical regions. However, trees reduce the light available for pastures, which may affect the growth and herbage accumulation. The objective of this study was to evaluate the morphogenesis, canopy structure and herbage accumulation of signalgrass (Brachiaria decumbens) subjected to three light regimes (0, 20 and $70 \%$ of natural shading) and two fertilization levels (presence or absence of nitrogen, phosphorus and potassium). Leaf and stem elongation rates increased under shading but did not vary with fertilization. The leaf appearance rate was greater under fertilizer treatment but was generally similar among light regimes. The tiller density was greater in full sun and lower in intense shading. Tiller density responded to fertilization under full sun and moderate shading. Herbage accumulation increased by $42 \%$ with fertilization under full sun, $12 \%$ under moderate shading and did not vary under intense shading. Results showed that even under fertilization the herbage accumulation was limited by reduced light. However, under moderate shade the fertilization was important to raise tiller population over the growth cycles.

Key words: Brachiaria decumbens, morphogenesis, shading, silvopastoral system, tiller density.
\end{abstract}

Morfologia e acúmulo de forragem de capim-braquiária com ou sem fertilização, sob diferentes regimes de luz

RESUMO: Os sistemas silvipastoris têm sido sugeridos como alternativa para recuperação de pastagens em regiões tropicais. Entretanto, as árvores reduzem a disponibilidade de radiação para o pasto, o que pode influenciar no crescimento e acúmulo de forragem. $O$ objetivo deste estudo foi avaliar a morfogênese, a estrutura do dossel e o acúmulo de forragem de Brachiaria decumbens, submetida a três regimes de luz (0, 20 e 70\% de sombreamento natural) e dois niveis de fertilização (presença ou ausência de nitrogênio, fósforo e potássio). As taxas de alongamento de folhas e colmos aumentaram com o sombreamento, mas não variaram com a fertilização. A taxa de aparecimento de folhas foi maior com a fertilização, mas, em geral, foi semelhante entre os níveis de sombra. A densidade de perfilhos foi maior no sol pleno e menor na sombra intensa. A densidade de perfilhos respondeu à fertilização sob sol pleno e sombra moderada. O acúmulo de forragem aumentou $42 \%$ com a fertilização no sol pleno, $12 \%$ na sombra moderada e não variou na sombra intensa. Os resultados mostraram que, mesmo com uso de fertilização, o acúmulo de forragem foi limitado pela redução de luz. Em condições de sombra moderada, a fertilização foi importante para aumentar a população de perfilhos ao longo dos ciclos de crescimento.

Palavras-chave: Brachiaria decumbens, densidade de perfilhos, morfogênese, sistema silvipastoril, sombreamento.

\section{INTRODUCTION}

Silvopastoral systems have been suggested as an alternative to recover degraded pastures and intensify animal production in ruminant grazing systems (XAVIER et al., 2014). Despite the benefits, the adoption of silvopastoral systems has been limited by insufficient knowledge about the management of their components. Study of morphogenesis may be useful in the design of more efficient management strategies that are based on the morphophysiological responses of plants to specific conditions in silvopastoral systems. Light restriction to the pasture may cause adaptive changes to growth patterns and sward structure. Under conditions of moderate shade, grasses can continue to grow at levels considered to be satisfactory, with an increase in the specific leaf area (GUENNI et al., 2008) and in the leaf elongation rate and leaf length (PACIULLO et al., 2008), and a reduction in the tillering rate (PACIULLO et al., 2008).

In many parts of south-eastern Brazil, the main soils are very acidic with low fertility, and the pastures typically have low carrying capacity. A series of studies performed in silvopastoral systems have shown only reasonable herbage accumulation and animal production in non-fertilized pastures (PACIULLO et al., 2011a). Improvement of soil nutrients through fertilization could increase herbage production in silvopastoral systems. However, under storey forages showed that lower light availability 
could affect the efficiency of pasture responses to fertilizers applications, which also depends on the availability of nutrients in the soil and in grass species (PACIULLO et al., 2011B; PANDEY et al., 2011). Some results have suggested the possibility of increasing herbage production in shaded conditions through the use of moderate doses of fertilizers (PANDEY et al., 2011).

The objective of this study was to evaluate the effect of three light regimes and two fertilization levels on the morphogenesis, structure and herbage accumulation of signalgrass.

\section{MATERIALS AND METHODS}

The experiment was carried out at Embrapa Dairy Cattle in the city of Coronel Pacheco, Minas Gerais, Brazil. The geographical coordinates are $21^{\circ} 33^{\prime} 22^{\prime \prime}$ south latitude, $43^{\circ} 06^{\prime} 15^{\prime \prime}$ west longitude, and the altitude is $410 \mathrm{~m}$. The climate, according to Köppen's classification, fits the Cwa type (mesothermal). The soil in the experimental field was a Red -Yellow Latosol (EMBRAPA, 1999), with undulated relief. The soil texture characteristics for the $0-20 \mathrm{~cm}$ layer included the following: coarse sand $=100 \mathrm{~g} \mathrm{~kg}^{-1}$, fine sand $=$ $280 \mathrm{~g} \mathrm{~kg}^{-1}$, silt $=190 \mathrm{~g} \mathrm{~kg}^{-1}$ and clay $=430 \mathrm{~g} \mathrm{~kg}^{-1}$. Soil analysis $(0-20 \mathrm{~cm}$ depth) showed the following results: $\mathrm{pH}$ in water, 4.7, exchangeable $\mathrm{Al}^{3+}, \mathrm{Ca}^{2+}+\mathrm{Mg}^{2+}$ and $\mathrm{K}^{+}$, $1.06,0.78$ and $0.12 \mathrm{cmolc}^{-3}$, respectively, available (Mehlich 1) P, 3.7 $\mathrm{mg} \mathrm{dm}^{-3}$ and organic matter, 3.3dag $\mathrm{kg}^{-1}$. The historical mean monthly rainfall and daily air temperature at the region, from October to March, are $230 \mathrm{~mm}$ and $24.0^{\circ} \mathrm{C}$, respectively. Climate data collected during the experimental period (mean monthly rainfall of $193 \mathrm{~mm}$ and daily air temperature of $24.1^{\circ} \mathrm{C}$ ) were close to historical climate data.

Evaluations were performed in a Brachiaria decumbens Stapf. cv. Basilisk pasture, established in 1997, in both a monoculture and a silvopastoral. Silvopastoral system consisted of the tree species Acacia mangium and Eucalyptus grandis, which measured 25 and $20 \mathrm{~cm}$ in diameter at breast height and 14 and $22 \mathrm{~m}$ in height, respectively. Trees were arranged in 10m-wide strips, and each strip included $3 \times 3 \mathrm{~m}$ spaced rows. Tree species were alternated within each row in each of the strips, and the distance between two strips of trees was $30 \mathrm{~m}$.

Applications of dolomitic limestone at the rate of $1,000 \mathrm{~kg} \mathrm{ha}^{-1}$, Araxa phosphate at $600 \mathrm{~kg} \mathrm{ha}^{-1}(5 \%$ of $\mathrm{P}_{2} \mathrm{O}_{5}$ soluble in citric acid), simple superphosphate at $250 \mathrm{~kg} \mathrm{ha}^{-1}$, potassium chloride at $100 \mathrm{~kg} \mathrm{ha}^{-1}$ and FTE (fitted trace elements) BR-16 (3.5\% of zinc, $1.5 \%$ of boron, $3.5 \%$ of copper and $0.40 \%$ of molibdenum) at $30 \mathrm{~kg} \mathrm{ha}^{-1}$ were made before planting the grass, in 1997. After establishment, pastures were managed with Holstein $\times$ Zebu heifers by the rotational stocking method. Pastures received no additional applications of fertilizers after planting in 1997.

For this study, the experimental area was prepared between March and October 2010 (plots allocation, elimination of some weeds, conditioning of the pasture height). Evaluations were conducted during the rainy season (November 2010 to April 2011), when $90 \%$ of annual rainfall occured. The experimental design was a randomized block (based on the slope of the area) with treatments arranged in a factorial of 3 degree of shadings $\times 2$ fertilizer (nitrogen, phosphorous and potassium - NPK) levels, with four replicates. Experimental units had an area equal to $20 \mathrm{~m}^{2}(5 \times 4 \mathrm{~m})$. The degree of shadings included the following: 1) control treatment representing full sun condition $=$ total transmitted PAR to pasture, 2) moderate shading = reduction of $20 \%$ of transmitted PAR and 3) intense shading = reduction of $70 \%$ of transmitted PAR. The average values of photosynthetically active radiation above the Brachiaria decumbens canopy were 1,187; 942 and $362 \mu \mathrm{m} \mathrm{m}^{-2} \mathrm{~s}^{-1}$, for full sun, moderate and intense shade, respectively. Full sun condition was attained in an open pasture; moderate shading was attained between 8 and $12 \mathrm{~m}$ from the tree rows, and intense shading was attained directly under tree canopy. The PAR measurements were made monthly using a canopy analyzer (AccuPAR LP 80, DECAGON Devices, Pullman, Washington, USA) on clear days (full sunlight) at 9:00h, 12:00h and 15:00h, to capture the day-to-day variation in sunlight. In each treatment, 15 readings were taken above the forage canopy. Readings were taken maintaining the bubble level of canopy analyzer centralized to keep the probe relatively level when making measurements.

The NPK levels corresponded to the presence or absence of soil fertilization. Plots received lime on the surface to increase the base saturation of the soil to $40 \%$. Fertilization with $\mathrm{N}, \mathrm{P}$ and $\mathrm{K}$ was divided in two split applications. The first application, after the standardization cut, used 40 , 60 and $40 \mathrm{~kg} \mathrm{ha}^{-1}$ of $\mathrm{N}, \mathrm{P}_{2} \mathrm{O}_{5}$ and $\mathrm{K}_{2} \mathrm{O}$ in the form of urea, single superphosphate and potassium chloride, respectively. The second application of $\mathrm{N}$ and $\mathrm{K}_{2} \mathrm{O}$ occurred after the second growth cycle using the same doses and sources. Total doses applied during experimental period were of $80 \mathrm{~kg} \mathrm{ha}^{-1}$ of $\mathrm{N}$ and $\mathrm{K}_{2} \mathrm{O}$ and $60 \mathrm{~kg} \mathrm{ha}^{-1}$ of $\mathrm{P}_{2} \mathrm{O}_{5}$.

The end of the regrowth period was determined by canopy height. The target to harvest 
was a canopy surface height of $40 \mathrm{~cm}$, a condition that, based on the results of a previous series of experiments under rotational stocking in the same area, resulted in high animal performance and satisfactory persistence of pasture over 10 years (PACIULLO et al., 2011a). Based on the height criteria, the period between harvests varied from 28 to 36 days. The used height of post-harvest residue was $20 \mathrm{~cm}$ (PACIULLO et al., 2011a).

Morphogenetic characteristics were estimated using marked tillers monitored during the period of regrowth. Six tillers in each plot were identified, totaling 24 tillers per treatment. These tillers were marked with a plastic ring and monitored once a week. The full length of the leaf blade was measured to ligule exposure. Length of emerging blades was measured from the tip to the ligule of the last expanded leaf, up to the point where its ligule was visible. The date that a leaf appeared was defined as the day when its ligule was first observed. Stem length was defined as the distance from the soil to the ligule of the youngest adult leaf and was measured at the beginning and the end of each evaluation period. Data were then used to calculate leaf appearance rate, which was calculated as the number of new leaves produced per tiller divided by the number of days of each assessment period. Leaf and stem elongation rates were calculated as the cumulative increase in leaf and stem length divided by the number of days in each assessment period. Total number of leaves per tiller was also determined.

Herbage mass was estimated from cuts within two $0.5 \times 0.5 \mathrm{~m}$ frames per plot allocated on two diagonally opposite quadrants. Cuts were made at ground level at the end of each growth cycle, when the canopy reached the average height of $40 \mathrm{~cm}$. Harvests were performance when the average height of all the four replications of each treatment reached the target of $40 \mathrm{~cm}$. After sampling (two samples per plot), canopy height of the whole plot was standardized to $20 \mathrm{~cm}$, and the other two points were sampled at ground level to estimate the residual mass. Samples were weighed, sub sampled and divided into live and dead components. Tillers were counted in the live fraction. The fractions were dried at $55^{\circ} \mathrm{C}$ for $72 \mathrm{~h}$ and then weighed. Herbage accumulation was calculated as the difference between herbage mass at the end of growth period (sward with $40 \mathrm{~cm}$ height) and the preceding residual dry mass (sward with $20 \mathrm{~cm}$ height). Total herbage accumulation, in the whole experimental period, was calculated as the sum of herbage accumulation in each growth cycle. For calculated herbage accumulation rate, herbage accumulation value was divided by the number of growth days.
Variance analysis of non-transformed data were performed using the PROC MIXED procedure of the SAS $^{\circledR}$ statistical package (Statistical Analysis System, version 9.0), which is appropriate for measurements repeated over time and for which time is investigated as a cause of variation. The variance and covariance matrices were chosen using the Akaike Information Criterion (WOLFINGER, 1993), and variance analysis was performed for the following variables: degree of shading, fertilization level, periods of regrowth and their interactions. Effects of shading, fertilization, growth cycle and their interactions were considered fixed while the experimental error between units and error for the same time unit were considered to be random effects. Treatment mean values were estimated using LSMEANS and the values were compared using difference probability (PDIFF) at the $5 \%$ probability level.

\section{RESULTS AND DISCUSSION}

The leaf and stem elongation rates did not respond to fertilization $(\mathrm{P}>0.05)$ but varied with the interaction between degree of shading and growth cycle $(\mathrm{P}<0.0001$ for leaf elongation and $\mathrm{P}=0.002$ for stem elongation rate) (Table 1). During the first, second and fourth cycles, there was generally a clear contrast among shading treatments with higher leaf elongation rate for intense shade, intermediate for moderate shade and lower for full sun condition. Differences in leaf and stem elongation rate among shading treatments disappeared during the third growth cycle. Regarding to the stem elongation rate, responses followed a similar pattern with higher and lower values for intense shade and full sun, respectively, except during the third cycle when no difference was observed (Table 1).

When compared to the full sun condition, the higher leaf and stem elongation rates in plants grown under shading indicates changes in the pattern of allocation of assimilates. Grasses respond to shade by allocating a higher proportion of carbohydrates to maintain or increase leaf area and stem length while decreasing dry matter for root growth (GUENNI et al., 2008). Acceleration of leaf growth can result in greater leaf expansion to improve light interception in lowlight environments (PACIULLO et al., 2011b). Longer internodal length under shade is also an attribute of morphological adaptation to a low light environment and might provide better spatial arrangement of leaves so that the plant can intercept and utilize available light more efficiently (LIN et al., 2001).

Leaf appearance rate varied with the interaction between degree of shading and fertilization 
Table 1 - Morphogenetic and structural traits of B. decumbens, according to degree of shading and growth cycle.

\begin{tabular}{|c|c|c|c|c|c|c|c|}
\hline \multirow{3}{*}{ Shade $(\%)$} & \multicolumn{4}{|c|}{ 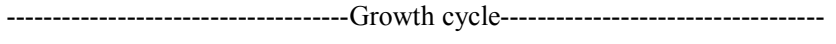 } & \multirow{2}{*}{ Mean } & \multirow{2}{*}{$P$-value ${ }^{1}$} & \multirow{2}{*}{ SEM } \\
\hline & 1 & 2 & 3 & 4 & & & \\
\hline & \multicolumn{7}{|c|}{ 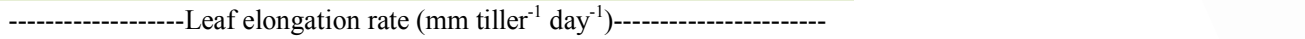 } \\
\hline 0 & $17.2^{\mathrm{Ac}}$ & $11.3^{\mathrm{Bc}}$ & $15.8^{\mathrm{Aa}}$ & $15.0^{\mathrm{ABb}}$ & 14.8 & \multirow{3}{*}{$<0.0001$} & \multirow{3}{*}{1.45} \\
\hline 20 & $23.1^{\mathrm{Ab}}$ & $16.1^{\mathrm{BCb}}$ & $12.7^{\mathrm{Ca}}$ & $18.7^{\mathrm{Bb}}$ & 17.7 & & \\
\hline 70 & $29.5^{\mathrm{Aa}}$ & $25.8^{\mathrm{Aa}}$ & $14.1^{\mathrm{Ba}}$ & $26.0^{\mathrm{Aa}}$ & 23.9 & & \\
\hline \multirow[t]{2}{*}{ Mean } & 23.3 & 17.7 & 14.2 & 19.9 & & & \\
\hline & \multicolumn{7}{|c|}{ 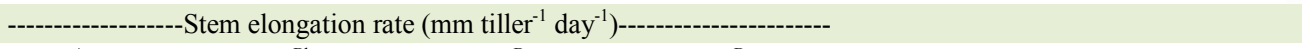 } \\
\hline 0 & $7.1^{\mathrm{Ac}}$ & $3.4^{\mathrm{Bb}}$ & $4.6^{\mathrm{Ba}}$ & $3.3^{\mathrm{Bc}}$ & 4.6 & \multirow{3}{*}{0.002} & \multirow{3}{*}{0.59} \\
\hline 20 & $9.3^{\mathrm{Ab}}$ & $4.2^{\mathrm{Bb}}$ & $3.7^{\mathrm{Ba}}$ & $5.1^{\mathrm{Bb}}$ & 5.6 & & \\
\hline 70 & $11.5^{\mathrm{Aa}}$ & $6.9^{\mathrm{Ba}}$ & $4.2^{\mathrm{Ca}}$ & $6.6^{\mathrm{Ba}}$ & 7.3 & & \\
\hline \multirow[t]{2}{*}{ Mean } & 9.3 & 4.8 & 4.2 & 5.0 & & & \\
\hline & \multicolumn{6}{|c|}{------------------------Number of live leaves per tiller--------------------------- } & \\
\hline 0 & $5.5^{\mathrm{Ab}}$ & $4.2^{\mathrm{Cb}}$ & $5.4^{\mathrm{ABa}}$ & $4.6^{\mathrm{BCb}}$ & 4.9 & & \multirow{3}{*}{0.13} \\
\hline 20 & $5.7^{\text {Aab }}$ & $5.1^{\mathrm{Ba}}$ & $4.8^{\mathrm{Bab}}$ & $5.3^{\mathrm{ABab}}$ & 5.2 & 0.0057 & \\
\hline 70 & $6.0^{\mathrm{Aa}}$ & $5.1^{\mathrm{Ba}}$ & $4.2^{\mathrm{Cb}}$ & $5.5^{\mathrm{ABa}}$ & 5.2 & & \\
\hline \multirow[t]{2}{*}{ Mean } & 5.7 & 4.8 & 4.8 & 5.1 & & & \\
\hline & \multicolumn{6}{|c|}{ 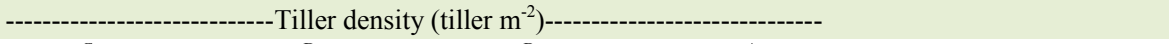 } & \\
\hline 0 & $711^{\mathrm{Ca}}$ & $618^{\mathrm{Da}}$ & $847^{\mathrm{Ba}}$ & $928^{\mathrm{Aa}}$ & 776 & & \multirow{4}{*}{38.3} \\
\hline 20 & $601^{\mathrm{Cb}}$ & $570^{\mathrm{Ca}}$ & $858^{\mathrm{Aa}}$ & $709^{\mathrm{Bb}}$ & 685 & 0.002 & \\
\hline 70 & $391^{\mathrm{Bc}}$ & $308^{\mathrm{Cb}}$ & $491^{\mathrm{Ab}}$ & $322^{\mathrm{BCc}}$ & 378 & & \\
\hline Mean & 568 & 499 & 732 & 653 & & & \\
\hline
\end{tabular}

For each variable, means followed by the same upper case letters in lines and lower case letters in columns are not different $(P>0.05)$.

${ }^{1}$ Probability of significant effect due to shade $\mathrm{x}$ growth cycle interaction. SEM = standard error of mean.

level ( $\mathrm{P}=0.029)$ (Table 2). Fertilization positively influenced the values except under moderate shading. No effect of the degree of shading was observed in the absence of fertilization. However, under fertilization, the leaf appearance rate was lower in moderate shade than in intense shade and full sun. Leaf life span was influenced only by the degree of shading $(\mathrm{P}=0.034)$ with the highest value estimated in moderate shade (60.2 days) compared to the other conditions which were similar (53.7 and 50.6 days for full sun and intense shading, respectively).

Number of live leaves per tiller was affected by the interaction between degree of shading and growth cycle $(\mathrm{P}=0.005)$ (Table 1$)$. The number of leaves per tiller increased with the degree of shading in the first, second and fourth cycles, while the value was larger under full sun and decreased with shading in the third cycle (Table 1).

The fertilization was effective at increasing the leaf appearance rate in full sunlight and intensive shade, suggesting a strategy in which plants direct greater amounts of nutrients to the synthesis of new leaves in the canopy. Increase in leaf appearance rate with fertilization was not accompanied by an increase in the number of leaves per tiller, which might mean a higher mortality rate for leaves subjected to the fertilization treatment. However, both leaf longevity and the number of leaves per tiller did not vary with fertilization. Furthermore, the leaf appearance rate remained practically unchanged under the different conditions of shading. Studies of morphogenesis in shaded grasses showed little or no effect of shading on leaf appearance rate (PACIULLO et al., 2011b) most likely due to the central role shading plays in the morphogenesis of plants. A contributing factor is that leaf appearance rate is the last modified trait for plant growth under adverse conditions.

Tiller density was influenced by the interaction between shading degree and growth cycle $(\mathrm{P}=0.002)$. Tiller density consistently was lower for intense shading than the other two conditions (Table 1). During the second and third growth cycles, moderate shade and full sun treatments showed similar results, but a larger tiller density was estimated in full sun than in intense shade during the first and fourth cycles. Tiller density was also influenced by the interaction between degree of shading and fertilization level $(\mathrm{P}=0.036)$ (Table 2). Differences were observed only in plants submitted to full sun and moderate shade where fertilization reflected in increase in tiller density of 24 and $18 \%$, respectively. In intense shading, there was no effect of fertilization 
Table 2 - Leaf appearance rate, tiller population density, herbage accumulation rate and herbage accumulation of $\boldsymbol{B}$. decumbens, according tc degree of shading and fertilization.

\begin{tabular}{|c|c|c|c|c|c|}
\hline \multirow{3}{*}{ Shade $(\%)$} & \multicolumn{2}{|c|}{---------------------------------Fertilization--------------------------------- } & \multirow{3}{*}{ Mean } & \multirow{3}{*}{$P$-value ${ }^{1}$} & \multirow{3}{*}{ SEM } \\
\hline & Present & Absent & & & \\
\hline & \multicolumn{2}{|c|}{--------------Leaf appearance rate (Leaf tiller ${ }^{-1}$ day $\left.^{-1}\right)$-------------- } & & & \\
\hline 0 & $0.1038^{\mathrm{Aa}}$ & $0.0875^{\mathrm{Ba}}$ & 0.0957 & \multirow{3}{*}{0.029} & \multirow{3}{*}{0.004} \\
\hline 20 & $0.0913^{\mathrm{Ab}}$ & $0.0944^{\mathrm{Aa}}$ & 0.0929 & & \\
\hline 70 & $0.1144^{\mathrm{Aa}}$ & $0.0963^{\mathrm{Ba}}$ & 0.1054 & & \\
\hline \multirow[t]{2}{*}{ Mean } & 0.1032 & 0.0927 & & & \\
\hline & 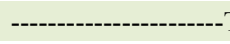 & 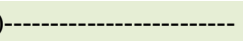 & & & \\
\hline 0 & $859^{\text {Aa }}$ & $693^{\mathrm{Ba}}$ & 776 & \multirow{3}{*}{0.0361} & \multirow{3}{*}{37.8} \\
\hline 20 & $743^{\mathrm{Ab}}$ & $626^{\mathrm{Ba}}$ & 685 & & \\
\hline 70 & $358^{\mathrm{Ac}}$ & $398^{\mathrm{Ab}}$ & 378 & & \\
\hline \multirow[t]{2}{*}{ Mean } & 653 & 572 & & & \\
\hline & ------------Herbage a & $\mathrm{kg} \mathrm{ha}^{-1}$ day $\left.^{-1}\right)$-------- & & & \\
\hline 0 & $54.4^{\mathrm{Aa}}$ & $36.1^{\mathrm{Ba}}$ & 45.3 & \multirow{3}{*}{0.0131} & \multirow{3}{*}{3.3} \\
\hline 20 & $37.7^{\mathrm{Ab}}$ & $31.9^{\mathrm{Aa}}$ & 34.8 & & \\
\hline 70 & $15.7^{\mathrm{Ac}}$ & $19.7^{\mathrm{Ab}}$ & 17.7 & & \\
\hline \multirow[t]{2}{*}{ Mean } & 35.9 & 29.2 & & & \\
\hline & ----------------Herba & 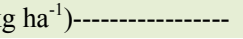 & & & \\
\hline 0 & $7,402^{\mathrm{Aa}}$ & $5,206^{\mathrm{Ba}}$ & 6,304 & \multirow{3}{*}{0.0165} & \multirow{3}{*}{410.1} \\
\hline 20 & $5,130^{\mathrm{Ab}}$ & $4,592^{\mathrm{Bb}}$ & 4,861 & & \\
\hline 70 & $1,961^{\mathrm{Ac}}$ & $2,343^{\mathrm{Ac}}$ & 2,152 & & \\
\hline Mean & 4,831 & 4,047 & & & \\
\hline
\end{tabular}

For each variable, means followed by the same upper case letters in lines and lower case letters in columns are not different $(P>0.05)$

${ }^{1}$ Probability of significant effect due to shade $\mathrm{x}$ fertilization interaction.

$\mathrm{SEM}=$ standard error of mean

on tiller density (Table 2). With fertilization, the tiller density was larger for full sun, intermediate for moderate shade and lower for intense shade. Without fertilization, full sun and moderate shade showed higher mean values than intense shade (Table 2).

There was a substantial reduction in the number of tillers due to the increased shading as noted by other authors (BARUCH \& GUENNI, 2007). Typically, to maintain the development of the tiller under shade, plants prioritize the growth of existing tillers at the expense of the production of new tillers. Changes in tillering are induced either by changes in the intensity or the quality of light intercepted by shaded plants. Higher tiller mortality may occur beyond axillary bud abortion even before the emergence of new tillers due to limitations in the supply of carbon generated by competition for light (KIM et al., 2010). Quality of light that passes through the arboreal canopy is altered by increased absorption at the wavelengths of blue and red. Thus, the light intensity in bands becomes smaller when compared to the green and far red spectrum, reducing the red/far red ratio. The decrease in this ratio in natural shade results in important morphogenetic responses in plants such as reductions in tillering (GAUTIER et al., 1999).

Shading was more limiting than the level of soil fertility to tiller density. In fact, light represents the most limiting resource for plant life and is critical for the acquisition of carbon and mineral nutrients (BARUCH \& GUENNI, 2007; PACIULLO et al., 2011b). The tiller density decreased gradually with the increase in shade level in fertilized plants; in the absence of fertilizer, tiller density in full sun and moderate shading was similar and reduced only with $70 \%$ of shade. These results confirmed the assertion that the level of radiation becomes more limiting to tillering than the availability of nutrients under conditions of excessive shading.

Even though the period of evaluation is not sufficient to conclude about pasture persistence, the comparisons of herbage accumulation rates observed by PACIULLO et al. (2008), in the same silvopastoral system, and those estimated in this study showed a clear trend regarding the persistence of the pasture. Values for full sun and moderate and intense shade were, respectively, 38; 32 and $41 \mathrm{~kg} \mathrm{ha}^{-1}$ day $^{-1}$ in 2006 
(PACIULLO et al., 2008), and 36; 32 and 20kg ha-1 day $^{-1}$, for the present study (Table 1). While values remained stable under full sun and moderate shade, a decrease of $51 \%$ in intense shade, after five years (2006 to 2011), represented a severe decrease in the herbage accumulation, which could affect pasture persistence.

The herbage accumulation rate was affected by the interaction between degree of shading and fertilization level $(\mathrm{P}=0.013)$. A clear advantage to fertilizer treatment was observed in the full sun condition compared with no fertilizer (Table 2). Although the difference between fertilization levels suggested a benefit for fertilized plots, there was no statistical significance between treatments under moderate shade. In the intense shade, no difference was observed. For total herbage accumulation, there were significant $(\mathrm{P}=0.016)$ responses to fertilization for full sun and moderate shading. The larger herbage accumulation was observed under full sun regardless of the fertilization level. Under intense shading, an accentuated reduction was observed for both fertilization levels (Table 2).

Literature indicated that shading above 40 $50 \%$ can affect the production of most forage grasses (BARUCH \& GUENNI, 2007; PANDEY et al., 2011), which was confirmed in this study by the lower herbage accumulation under shading treatments, compared to full sunlight. Although signalgrass presents morphophysiological adjustments as a strategy for shade tolerance (GUENNI et al., 2008), such mechanisms have been unable to compensate for the reduction of radiation and to maintain pasture productivity under conditions of intense shading. LEE \& YUN (1985) have reported that tiller density and dry matter yield increased with enhanced NPK rates while decreases occurred with shading. In the same study it was concluded that optimum rates of fertilizers depend on shading intensity, and forests with $40 \%$ or more shade offered no prospect for pasture improvement. In fact, in an endeavor to increase light absorption to compensate for lower levels of irradiance, the morphogenetic adjustments were effective under moderate shading with no fertilizer, and the treatment showed similar accumulation rates to full sun (Table 2).

For total herbage accumulation, the difference was small in magnitude but was statistically significant. However, the data show that total herbage accumulation increased with fertilization by 42 and $12 \%$ for the conditions of full sun and moderate shading, respectively. XAVIER et al. (2104) evaluated the $\mathrm{N}$ cycling in the same silvopastoral system of our experiment and have estimated the input of $\mathrm{N}$ to the pasture from senescent legume tree leaves varying between 15.4 and $19.7 \mathrm{~kg} \mathrm{ha}^{-1}$ year $^{-1}$, which could have influenced plant responses to $\mathrm{N}$ applied in shading conditions. However, the amount of $\mathrm{N}$ from legume trees (XAVIER et al., 2014) can be considered low to affect the pasture response to $\mathrm{N}$ applied or even to influence the herbage production under shading condition. The literature demonstrated that plants cultivated under shade, especially under intense shade, have increased $\mathrm{N}$ content in tissues, without a correspondent increase in biomass production (GENNI et al., 2008). The reduction of radiation available for pasture growth, imposed by the tree component of the silvopastoral system, limits the use of nutrients from fertilization. Results also showed that the efficiency of fertilization, indicated in this case by the accumulation rates under different conditions, is inversely proportional to the level of shading imposed on a pasture, as observed by GUENNI et al. (2008) and PACIULLO et al. (2011b). These observations are consistent with the response pattern observed in other studies with grasses that have shown increases in forage production in silvopastoral systems with Eucalipytus spp. in response to fertilization but with values significantly below those observed in pastures without interference of an arboreal component (PANDEY et al., 2011).

In tropical areas with low fertility soils, the use of moderate doses of fertilization is an alternative to improve herbage production in full sun. In silvopastoral systems under moderate shading, the magnitude of responses to fertilization was lower than those obtained in full sun; although, fertilization was effective to increases tiller density and herbage accumulation.

\section{CONCLUSION}

Under fertilization, the shading level becomes the primary limiting factor influencing tiller density and herbage accumulation. Although signalgrass showed morphogenetic adjustments in response to reduction in photosynthetic active radiation, intensive shading should be avoided because it may threaten pasture persistence over time, because it greatly reduces tiller density and herbage accumulation. Although the fertilization markedly increased herbage accumulation of signalgrass in full sun, under moderate shade it was observed a slight increase. Under moderate shade fertilization is more important to raise tiller population, contributing for pasture persistence, than to increase herbage production. 


\section{ACKNOWLEDGEMENTS}

The authors thank the Fundação de Amparo a Pesquisa de Minas Gerais (FAPEMIG) for funding of this research.

\section{REFERENCES}

BARUCH,Z.; GUENNI, O. Irradiance and defoliation effects in three species of the forage grass Brachiaria. Tropical Grasslands, v.41, p.269-276, 2007. Available from: <http://www.tropicalgrasslands. asn.au/> Accessed: May 05, 2016.

GAUTIER, H. et al. Tillering responses to the light environment and to defoliation in populations of perennial ryegrass (Lolium perenne $\mathrm{L}$.) selected for contrasting leaf length. Annals of Botany, v.83, p.423-429, 1999. Available from: $<\mathrm{http}$ ///aob.oxfordjournals.org/ content/83/4/423. abstract $>$. Accessed: May 09, 2016. doi: 10.1006/anbo.1998.0840.

GUENNI, O. et al. Growth responses of three Brachiaria species to light intensity and nitrogen supply. Tropical Grasslands, v.42, p.7587, 2008. Available from: <http://www.tropicalgrasslands.asn.au/>. Accessed: May 09, 2016

KIM, H.K. et al. Regulation of tillering in sorghum: environmental effects. Annals of Botany, v.106, p.57-67, 2010. Available from: $<$ http://aob.oxfordjournals.org/content/106/1/57.short $>$. Accessed: May 09, 2016. doi: 10.1093/aob/mcq079.

LEE, I, D. et al. Studies on improvement and utilization of pasture in the forest. The effect of shade degree and fertilization levels on the early seedling growth and dry matter yield of forest pastures. Journal of the Korean Society of Grassland Science, v.5, p.162-166, 1985. Available from: $<$ http:/www.koreasicence.or.kr/journal/Aboutjournal. Jsp?kojic=GCJHBG $>$. Accessed: May, 09, 2016.

LIN, C.H. et al. Nutritive quality and morphological development under partial shade of some forage species with agroforestry potential Agroforestry Systems, v.53, p.269-281, 2001. Available from: <http://
link.springer.com/article/10.1023\%2FA\%3A1013323409839\#>. Accessed: May 09, 2016. doi: 10.1023/A:1013323409839.

PACIULLO, D.S.C. et al. Crescimento do pasto de capim-braquiária influenciado pelo nível de sombreamento e pela a estação do ano. Pesquisa Agropecuária Brasileira, v.43, n.7, p.317-323, 2008. Available from: <http://www.scielo.br/pdf/pab/v43n7/17.pdf $>$. Accessed: Aug. 25, 2016. doi: 10.1590/S0100-204X2008000700017.

PACIULLO, D.S.C. et al. Performance of dairy heifers in a silvopastoral system. Livestock Science, v.141, p.166-172, 2011a. Available from: $<$ http://www.sciencedirect.com/science/ article/pii/S1871141311001971>. Accessed: May 09, 2016. doi: 10.1016/j.livsci.2011.05.012.

PACIULLO, D.S.C. et al. The growth dynamics in Brachiaria species according to nitrogen dose and shade. Revista Brasileira de Zootecnia, v.40, p.270-276, 2011b. Available from: <http://www.scielo.br/ scielo.php?script=sci_arttext\&pid=S1516-35982011000200006>. Accessed: May 09, 2016. doi: 10.1590/S1516-35982011000200006.

PANDEY, C.B. et al. Forage production and nitrogen nutrition in three grasses under coconut tree shades in the humid-tropics. Agroforestry Systems, v.83, p.1-12, 2011. Available from: <http://link.springer. com/article/10.1007\%2Fs10457-011-9407-2\#>. Accessed: May 09, 2016. doi: 10.1007/s10457-011-9407-2.

WILSON JR. Influence of planting four tree species on the yield and soil water status of green panic pasture in subhumid south-east Queensland. Tropical Grasslands, v.32, p.209-220, 1998. Available from: <http:// www.tropicalgrasslands.asn.au/>. Accessed: Aug. 26, 2016.

WOLFINGER, R. Covariance structure selection in general mixed models. Commun Stat, v.22, p.1079-1106, 1993.

XAVIER, D.F. et al. Nitrogen cycling in a Brachiaria-based silvopastoral system in the Atlantic forest region of Minas Gerais, Brazil. Nutrient Cycling in Agroecosystems, v.99, p.45-62, 2014. Available from: $<$ http:// link.springer.com/article/10.1007/s10705-014-9617-x>. Accessed: Aug. 26, 2016. doi: 10.1007/s10705-014-9617-x. 